\title{
Bércesi Richárd \\ A PÉCSI BÁNYAVIDÉK ELEMI ISKOLÁINAK HÁLÓZATI RENDSZERE 1856 ÉS 1944 KÖZÖTT
}

\section{Absztrakt}

Publikációm témája az Első Dunagőzhajózási Társaságnak (a továbbiakban: DGT) az 1880-as években a pécsi bányavidéken létrehozott és 1944 novemberéig működtetett elemi iskolai hálózata, amely a bányatörténettel való személyes érdeklődésemen alapuló kutatásom része. Több kérdés is foglalkoztatott: Hol és mennyi oktatási intézményt működtetett a cég? Milyen jellegű oktatás (képzés) zajlott az iskolákban? Csak bányászcsaládok gyermekei, vagy mások is lehettek az intézmények diákjai? Ingyenes volt az oktatás, és ha igen, akkor mindenki számára? Csak a fenntartásban volt érdekelt a vállalat, vagy tanszereket is biztosítottak a diákoknak? Milyen fokú volt az állami ellenőrzés? Történt-e bármilyen jellegű változás a DGT iskolahálózatának működtetésében, az intézmények mindennapi életében és az oktatásban az 1938. március 12-ei Anschluss után? ${ }^{1}$ Továbbéltek a bányászhagyományok 1944, a szovjet megszállás, majd az államosítás után?² Vizsgálataim során a Tudásközpont helytörténeti részlegének szakirodalmát, a Magyar Nemzeti Levéltár (röviden: MNL) DGT-anyagát, továbbá a Pécsi Bányásztörténeti Alapítvány (röviden: PBA) relikvia és fényképgyűjteményét dolgoztam fel, valamint interjúkat is készítettem. Összegezve arra a következtésre jutottam, hogy a DGT-iskolák a magyar oktatástörténeten belül sajátos szerepben voltak: az államtól kapott különleges privilégiumoknak köszönhetően az iskolai élet minden területén a fenntartó hozhatta meg a kulcsfontosságú döntéseket, miközben a Vallás és a Közoktatásügyi Minisztérium (a továbbiakban: VKM), majd 1938 után német részről erőteljes asszimilációs törekvéseknek voltak kitéve az intézmények.

Kulcsszavak: DGT elemi iskolák; működtetés; egyediség.

\section{Bevezető}

A DGT 1853-as pécsi megtelepedése sosem látott fejlődést eredményezett a város, valamint az iparág helytörténetében. A kialakulóban lévő pécsi bányavidék társadalmának élete, sorsa generációkon át, közel egy évszázadon keresztül, teljes mértékben az itt élő emberek számára a munkát adó vállalattól függött. A cég biztosította a lakhatást, a fűtésre szánt feketekőszenet, a szociális juttatásokat, sőt az élelmitárak, és húsfüstölők révén még egy bizonyos fokig az élelmet is.

\footnotetext{
${ }^{1} \mathrm{Az}$ elnevezés Ausztria náci Németországhoz csatolására utal, amely után egy nappal az osztrákokhoz hasonlóan, a DGT magyar tulajdonosai is „önként” bejelentették csatlakozásukat a „Reichwerke Hermann Göring” vállalathoz, amellyel a társaság elvesztette az önállóságát.

2 Pécs szovjet megszállásának kezdetétől, 1950. decemberéig a teljes egykori DGT vagyon, és a pécsi bányavidék felett (mint hadizsákmány), kizárólag a Szovjetunió rendelkezett.
} 
De vajon az oktatás területén mi volt a helyzet? A cég első pécsi kőszénbányájának, Andreas-Schachtnak ${ }^{3}$ a megnyitása, valamint a tankötelezettség bevezetése között másfél évtized telt el, annak ellenére is, hogy a Habsburg kormányzat már „erősen ajánlottá” tette a rendszeres iskolalátogatást (Katus, 2010, p. 503).

A DGT-nek képzett alkalmazottakra volt szüksége a szakszerű bányaműveléshez, amely kulcsfontosságú volt a vállalat működtetésének, a tulajdonában lévő gőzhajók fütésének szempontjából, mivel a pécsi nyersanyaglelőhely kiváló minőségű feketekőszenet rejtett magában. Ahhoz, hogy a kőszénbányászat generációkon keresztül fennmaradjon, a kolóniákon a legalsó szinttől kellett megszervezni egy olyan rendszeres, iskolában történő oktatást, amely az alapfokú ismeretek átadása mellett, (bányász) identitásképző erővel is bírt (Huszár, 2013, p. 151).

E szempontok figyelembevételével teszek kísérletet a pécsi bányavidéken az elemi iskolai hálózat kialakulásának, az intézmények belső életének, működésüknek és az oktatásszervezésnek az ismertetésére, valamint az állami fenntartású iskolákkal szembeni különbségeiknek (az Osztrák-Magyar Monarchia és a Horthy-korszakbeli magyar elemi szintű oktatási rendszer jellegzetességeinek az összefoglalásával történő) elemzésére.

Vizsgálataimnak ezért nem volt része a szakmai képzést nyújtó középfokú oktatás.

\section{A magyar elemi színtű oktatási rendszer az Osztrák-Magyar Monarchia korában (1867-1914) és a Horthy-korszakban (1920- 1944)}

A modern oktatási rendszer alapjainak lerakása báró Eötvös József nevéhez füződik, aki az 1868-as népiskolai törvénnyel (1868: XXXVIII. tc.) alakította ki a korszak alapfokú oktatásának működtetését. Mivel munkámban a pécsi bányavidéknek csak az elemi iskolai hálózatát mutatom be, ezért ebben a fejezetben kizárólag a népiskolai törvényt helyezem górcső alá.

Az elemi népiskolai rendszerben hat osztályt kellett elvégezniük a diákoknak, amelyből ha négyet már sikeresen teljesítettek, akkor lehetőségük volt arra, hogy tanulmányaikat a középiskolában folytathassák. Akik a maradás mellett döntöttek, azok számára a képzés elvégzése után az ismétlőiskola volt a következő, kötelező lépcsőfok, amelyet 15 évesen fejezhettek be.

Elemi szinten az oktatás 1879-ig anyanyelven zajlott, bármilyen nemzetiségről legyen is szó. Ezt követően, az 1879. XVIII. tc. már a kötelezővé tette a magyar nyelv, mint tantárgy oktatását minden elemi iskola számára.

1914-ig az oktatási intézmények száma 13 798-ról 16 929-re, és a tanítóké is a duplájára nőtt. A képet azonban némileg árnyalta az a tény, hogy a magyarországi oktatási intézmények több mint felében a korszak végéig általában egy közös tanteremben, egy tanárral zajlott az oktatás (Katus, 2010, p. 503). 
Az Eötvös-féle kultúrpolitika az Osztrák-Magyar Monarchia időszakának az elején hadat üzent az analfabétizmusnak, és célul tűzte ki, hogy minél több gyermek tanuljon meg írni és olvasni. Az Osztrák-Magyar Monarchiában, 1910-ben tartott utolsó népszámlálás adataiból kiolvasható, hogy ez a hátrány valóban jelentős mértékben visszaszorult a Magyar Korona Országaiban. A probléma az volt, hogy ez korántsem egységesen történt meg az ország különböző részein élő nemzetiségek között. A németekkel (82\%), a magyarokkal (79\%) és a szlovákokkal (70\%) szemben a horvátok, és a szerbek közel fele (56\%, 48\%), míg a románoknak (33\%), és a ruszinoknak (28\%) csak a töredéke volt képes írni és olvasni (Katus, 2010, p. 503).

Európai szinten azonban Magyarország a középmezőnybe tartozott, ugyanis a rangsorban a legrosszabbul teljesítő Orosz Birodalom és a Balkán-félsziget országai mellett egy frissen érkezett európai középhatalmat, Olaszországot is sikerült maga mögé utasítania. A Monarchia osztrák (81\%) és cseh területeihez (90\%) képest Magyarország azonban lemaradásban volt. Ezzel szemben a többi, szlávok és részben románok lakta területekhez (pl.: Dalmácia, Bukovina, Galícia) képest előnyösebb volt a helyzete, ahol még 1914-ben is a lakosság alig kevesebb, mint fele analfabéta volt (Katus, 2010, pp. 503504).

A magyar oktatás fejlesztésére nagy hangsúlyt helyeztek a vesztes első világháború után is. A Horthy-korszak első felének vallás-, és közoktatásügyi minisztere, Klebelsberg Kunó meghirdette a „kultúrharc” elvét. A tárcavezető meglátása szerint Trianon „sokkjának” első, megvalósítható gyógymódja nem más, mint a Kárpát-medencén belüli kultúrfölény megszerzése a többi itt élő néppel szemben, mert ez az első lépcsőfok afelé, hogy Magyarország megvalósíthassa a revíziót, vagyis az 1920 előtti államhatárok visszaállítását. A kormány ezért a miniszter javaslatára az állam éves költségvetésének jelentős részét (a kiadások 9-10\%-át) az oktatásra fordította, amelyre az Országgyűléstől is felhatalmazást kapott (Huszár, 2013, pp. 202-203).

Klebelsberg 1926-ban új népiskolai törvényt fogadtatott el az Országgyűléssel, és a teljes oktatási rendszert megreformálta. Ennek eredményeképpen miniszterségének végére Magyarországon kb. 14\%-ról 7\%-ra szorult vissza az analfabétizmus. A tárcavezető iskolaépítési programot hirdetett („népiskolai program”), amelynek keretében 3500 új tanterem, valamint 1500 tanítói (szolgálati) lakás épült a vidéki falvakban (Ormos, 1998, p. 115).

A beruházásokat utóda, a Horthy-korszak második felének vallás-, és közoktatásügyi minisztere, Hóman Bálint is folytatta. Abban a tekintetben viszont szakított a korábbi klebelsbergi oktatáspolitikával, hogy még nagyobb hangsúlyt helyezett a „hazafias nevelésre”, az iskolai tantárgyak „nemzeti” jellegére, akár humán, akár reáltárgyakról volt szó. A diákok számára előírta a kötelező díszegyenruha viselését a nemzeti ünnepeken, valamint a gyásznapon, a Trianoni békeszerződés június 4-ei aláírásának évfordulóján.

Ezek a tények azonban semmit nem vonnak le abból, hogy a magyar oktatás megbízható alapokon nyugodott, és a tehetséges diákok számára megadta a lehetőséget arra, hogy ki tudjanak törni az elszigeteltségből, és középiskolai tanulmányaik után akár egyetemre is mehessenek (Ormos, 1998, p. 204). 
Az említett miniszterek rendeletei és az elfogadott oktatási törvények Magyarország összes intézményére (elvileg) kivétel nélkül kötelező érvénnyel bírtak. Pécsen, a DGT által fenntartott iskolák esetében a fenntartónak a VKM-től kapott kivételes jogosítványai miatt azonban eltérések voltak (Mendly, 2005, p. 218).

\section{A DGT elemi iskolahálózatának kiépülése (1856-1892)}

\section{A Pécs-Bányatelepi iskola}

A DGT első elemi iskoláját 1856-ban nyitotta meg Pécs-Bányatelepen. A társaság már 1853 óta működtette első saját szénbányáját, Andreas-Schachtot, de a kezdeti években a dolgozók gyerekei számára még volt elegendő férőhely a pécsi egyházi iskolák valamelyikében, ezért a vállalatnál ekkoriban nem gondoltak egy helyi oktatási intézmény létesítésére (Huszár, 2013, p. 151).

Három éven belül azonban ez a helyzet megváltozott, mivel nemcsak a lakosságszám növekedett folyamatosan a kolónián, hanem ennek okán már az is komoly problémát jelentett, hogy a legközelebbi iskola kb. 5 km-re, a történelmi Pécs városfalán belül feküdt, és itt már hely sem nagyon volt az újonnan betelepülő családok gyerekei számára. A diákok hajnalban, a korabeli viszonyok között gyalog, vagy lovas kocsin tudtak csak eljutni az iskolába. A téli időszakban már e tényezők mellett is komoly ellenfél volt az időjárás, mivel a hó miatt az utak járhatatlanok voltak, és ez sokakat meggátolt abban, hogy biztonságosan megérkezhessenek a tanórájukra. A helyzet tarthatatlanná vált, mivel az ekkor regnáló neoabszolutista Bach-rendszer már rendeletileg „erősen ajánlottá” tette (de még nem kötelezővé) a rendszeres iskolalátogatást (Katus, 2010, p. 147), amelyet az egyre növekvő számú pécs-bányatelepi gyerekek számára is helyi szinten elérhetővé kellett tenni. E szempontok miatt a DGT az iskolaalapítás mellett döntött (Babics, 1952, p. 143).

Az intézményben ekkor még csak a bányászcsaládok gyermekei tanulhattak. Az oktatás német nyelven folyt, egy tanítóval. Ennek oka nem csak a Bach-rendszer németesítési törekvése volt, hanem az is, hogy a kolónián elsősorban német anyanyelvűek, illetve cseh, morva és szlovén eredetű (birodalmi) szlávok éltek. A magyarok csak csekély számban telepedtek le itt (Huszár, 2009, pp. 55-56.), többségük Pécsről járt ki dolgozni a bányába (Márfi Attila, 2017. március 10.).

Az 1860-as évekre a cégcsoport hajóparkjának állandó bővülése együtt járt a pécsi bányavidéken való folyamatos terjeszkedéssel, ugyanis a kazánok fütéséhez nyersanyagra volt szükség. A cég sorra felvásárolta a környező kis bányákat, amelyek már alig bírták az erős konkurenciával való versenyt. A kialakulóban lévő ipari centrum új munkaerőt is igényelt (Mendly, 2005, pp. 177-178). A Pécs-Bányatelepre érkező bányászok általában nem egyedül költözködtek a kolóniára, ha viszont igen, akkor később itt alapítottak családot (Gergely, 1986, pp. 296-307).

Az egyre nagyobb számú lakosság több oktatót igényelt az iskolába is, ezt a vonatkozó statisztikák is bizonyítják: 1865-ben kettő, öt évvel később, 1870-ben pedig már hat tanító rendelkezett állással a pécs-bányatelepi iskolában (MNL DGT Z 269 17. csomó, 2. tétel). 
A kolónia folyamatosan növekvő lélekszámának tudható be az a tény is, hogy 1869-ben báró Eötvös József vallás-, és közoktatásügyi miniszter rendeleti úton tette lehetővé azt, hogy minden gyerek a származásától függetlenül az intézményben tanulhasson. A fenntartói jogok azonban a DGT kezében maradtak, de az oktatást az állam felügyelte a kerületi tanfelügyelőkön keresztül. A tanfelügyelők feladatkörének legfontosabb része az egyes tanórák mindent átfogó megfigyelése volt, ahol azt kellett ellenőrizniük, hogy megjelennek-e az adott oktató munkájában a minisztérium által meghatározott pedagógiai-szakmódszertani elvek. Benyomásukat a jelentésük mellett, az adott iskola vezetőségével és oktatójával is közölték, mégpedig egy összoktatói értekezlet keretein belül (Huszár, 2013, p. 151).

Az iskola számára ekkor egy új, a korábbinál nagyobb épületet emeltek (Huszár, 2010, pp. 117-118), amely Czerékvölgyből Pécs-Bányatelep délnyugati részére költözött át. Az iskola új, korszerűbb, sokkalta tágasabb, emelettel is rendelkező otthonában az újdonságnak számító koedukáltság jegyében önálló, nemek szerint elkülönített mellékhelységek kialakítására is sor került. A régi iskolaépületet a kiköltözés után lakóházzá alakították át (Traj Ferenc, 2017. február 28.).

A XIX. század végére a folyamatos tanulói létszámnövekedés miatt azonban ezt a létesítményt is „kinőtte” az intézmény, ezért tőle északabbra, Pécs-Bányatelep középső részén a DGT létrehozott egy második iskolát is. Az új építmény belső elrendezése 5 tanteremre, 1 munkateremre, külön tanári-, és igazgatói irodára oszlott (MNL DGT Z 271 d, 84. csomó, 155. tétel).

A kolónia lakossága ezt követően a két párhuzamosan működő intézmény megkülönböztetésére az „alsó” és a „felső” iskola megnevezéseket használta (Traj Ferenc, 2017. február 28.), ahol tíz-tíz tanító oktatta a nebulókat (MNL DGT Z 269 17. csomó, 2. tétel).

A fejlesztések terén azonban egy hiányossága mégis volt mindkét iskolának. Noha kint nagy udvarral rendelkeztek, belül kevés volt a szabad tér a diákok számára. A nagy kiterjedésű tantermek miatt nem került sor a tágas folyosók, zsibongók kialakítására, ahol a diákok a rossz idő esetén a tanórák közötti szüneteket tölthették. Ezt a hiányt egy nyitott verandával szerették volna pótolni a tervezők, ettől azonban a probléma nem szűnt meg az intézményekben (MNL DGT Z 271 d, 84. csomó, 155. tétel).

\section{A mecsekszabolcsi iskolák}

A DGT 1865-ben két új szénbányát nyitott a Pécs melletti Mecsekszabolcson, a Ferenc József-, ${ }^{4}$ valamint György-aknát. Az eredetileg Árpád-kori mecseki kisközség lélekszáma ekkor kezdett jelentősebben emelkedni, amelynek bizonyítéka, hogy 1872-ben itt kezdte meg működését a cég által létesített második elemi iskola (Pilkhoffer, 2010, p. 140).

Az iskolaalapítás előzményeihez hozzátartozik, hogy a vállalat és a pécsi püspök5között 1870-ben egy szerződés köttetett, amely rendelkezett egy elemi iskola létesítéséről az itt élők számára. A megállapodás részét képezte, hogy az iskola (a pécs-bányatelepi

${ }^{5} \mathrm{~A}$ község és környékén lévő szénmező a székesegyházi uradalom birtokában volt. A DGT bányaművelésre bérelte a területet, az általa kitermelt nyersanyag 30\%-a a püspököt illette. 
létesítménytől eltérően) egyházi jellegű oktatási intézményként működjön (Huszár, 2010, p. 118). Az egyház nemcsak a felekezetiséget, hanem az oktatás nyelvét is előírta a társaság által múködtetett iskola számára, amely a pécs-bányatelepivel ellentétben csak és kizárólag a magyar volt (Huszár, 2009, p. 58).

Az első tanévben összesen 50 diák járt a mecsekszabolcsi iskolába (MNL DGT Z 26917. csomó, 1. tétel), akik három tagozaton, egy osztályos évfolyamokon tanulhattak.

A modernnek számító iskolaépület a tanulók létszámának növekedésével párhuzamosan, az évek során többször is átépítésre került, 1944-re a belső elrendezése az ekkor már két pécs-bányatelepi iskolához hasonlóan 5 tanteremre, 1 munkateremre, külön tanítói, és igazgatói irodára oszlott. (Pálfy, 2005, p. 266).

A kialakításából eredő hiányossága szintén megegyezett a pécs-bányatelepi intézményekkel. Noha kint nagy udvarral rendelkezett, belül kevés volt a szabad tér a diákok számára. Nem került sor a tágas folyosók, zsibongók kialakítására, ahol a tanulók a rossz idő esetén a tanórák közötti szüneteket tölthették, a közlekedők meglehetősen szűkösek voltak (MNL DGT Z 271 d, 84. csomó, 155. tétel).

1874-ben, a DGT és a pécsi püspökség szerződésében foglaltaknak megfelelően, a társaság az egyházmegye által működtetett György-aknai (felső) elemi iskolát is átvette (Pálfy, 2005, p. 266). A püspök a déli iskolához hasonló elveket fogalmazott meg a cég számára az oktatás nyelve, valamint a felekezetiség vonatkozásában (Mendly\&Romváry, 2005, p. 32).

\section{A vasasi iskola}

A DGT az 1860-as évek végén szénbányát nyitott egy másik Pécs melletti községben, Vasason is. Thommen-akna ${ }^{6}$ felszentelését ${ }^{7}$ követően erre a településre is megindult az Osztrák-Magyar Monarchia cseh-morva területeiről az új munkaerő áramlása (Pilkhoffer, 2010, p. 143).

Akárcsak a többi DGT-kolónián, a cég 1873-ban Vasason is a saját kezébe vette az oktatást. Itt azonban már az 1860-as évektől működött egy elemi iskola, amelyet a környékbeli kis magánbányák alkalmazottai tartottak fenn a saját költségükből, bár egyre nehezebb körülmények között. A cég úgy orvosolta a problémát, hogy a vallás-, és közoktatásügyi miniszter engedélyével átvette a fenntartási jogokat a bányászoktól, az oktatást pedig az állam ellenőrizte.

A váltás sok szempontból is jót tett a vasasi iskolának. A DGT a korábbiakhoz képest egy újabb, tágasabb épületet biztosított számukra, bár így is három évfolyam tanult együtt (MNL DGT Z 271 d, 84. csomó, 155. tétel) egy osztályteremben (Romváry, 2008, p. 27). Az intézménybe összesen 41 tanuló járt (MNL DGT Z 269 17. csomó, 1. tétel).

\section{A somogyi iskola}

1898-ban egy újabb baranyai településen, Somogyban (MNL DGT Z 271 d, 84. csomó, 155. tétel) került a társaság fenntartása alá a korábban egyházi kézben lévő elemi iskola 
(Huszár, 2009, p. 59). A cég felújítatta, és bővítette is az intézményt, ahol a korábbi eggyel szemben, immáron két tanterem várta az átalakítások után a nebulókat (Babics, 1952, p. 143). Az iskolába összesen 32 tanuló járt (MNL DGT Z 269 17. csomó, 1. tétel).

Az átvétellel befejeződött a DGT iskolahálózatának kialakítása (Huszár, 2010, p. 118).

\section{A DGT elemi iskolák: A történelmi Magyarország vidéki, magánkézben lévő, modern és korszakalkotó oktatási intézményei}

A DGT által létesített oktatási intézmények egészen a második világháború végéig modernnek és korszakalkotónak számítottak (Huszár, 2007, pp. 254-275). Az épületek esetében nem csak a több tanteremre bomló tér kihasználására, hanem már a létesítményeknek az elhelyezkedésére is komoly figyelmet fordítottak a tervezők. Az iskolákat rendszerint a bányaüzemektől távolabb, jórészt az erdő mellett igyekeztek kialakítani, amelynek oka az volt, hogy „a gyerekek ne a rossz füstszagot, hanem az egészséges erdei levegőt szívhassák magukba, amely a koncentráló-, és a teljesítőképességet is javítja”- legalábbis a vállalat hivatalos kommunikációja szerint (Huszár 2013, p. 155).

Az iskolák közös jellemzője volt, hogy nagy udvarral rendelkeztek, ahol alkalomadtán sportolásra is lehetősége volt a tanulóknak. Az épületekben egyébként meglehetősen kicsi, de használható tornaszobákat is kialakítottak, amelyek ugyancsak a modernizációt volt hivatottak képviselni egy XIX. század végi magyar oktatási intézményben (Huszár, 2013, p. 155).

A diákok iskolai tanulmányaihoz, az egyéni művelődésükhöz úgy próbált segítséget nyújtani a társaság, hogy minden iskola számára külön könyvtárat létesített az adott intézményen belül, amelyek a korban gazdagnak számító gyűjteménnyel, 700-800 könyvvel is büszkélkedhettek. A könyveket elsősorban a cég vásárolta, de önkéntes felajánlásokat is elfogadtak a kolóniák lakóitól (Huszár, 2013, p. 160-161).

Az újdonságnak számító koedukáltság jegyében önálló, nemek szerint elkülönített mellékhelységek kialakítására is sor került (MNL DGT Z 271 d, 84. csomó, 155. tétel).

A tanítók számára a társaság biztosított lakást. Pécs-Bányatelepen és Vasason az iskolákhoz tartozó melléképületekben kerültek kialakításra, míg Mecsekszabolcson, valamint Somogyban az egyháztól béreltek épületet a tanítók elszállásolása céljából (Huszár, 2013, p. 155).

\section{A DGT kapcsolata az általa épített, de más fenntartó alatt álló iskoláival: a Gyárvárosi Iskola és az Ullmann-telepi Iskola}

Az 1920-as években, a klebelsbergi oktatási reformok adtak ismét támogatást ahhoz, hogy a társaság belevágjon újabb oktatási intézmények létesítésébe, amelyek azonban már nem a cég, hanem Pécs városa és a Római Katolikus Egyház fennhatósága alatt működtek (MNL DGT Z 271 d, 84. csomó, 155. tétel).

Huszár Zoltán „A Duna vonzásában: Fejezetek a Dunagőzhajózási Társaság történetéből" című munkájában rámutat arra, hogy a Klebelsberg Kunó által az Országgyúlésnek benyújtott, majd elfogadott 1926. VII. tc. volt a DGT beruházások 
felélesztése szempontjából a döntő momentum. A negyedik paragrafus lehetővé tette, hogy „Az iskola érdekeltsége és az iskola létesítési költségeinek megoszlása fejében, a társulati adó kivetése alapjául szolgáló jövedelem arányában" (Huszár, 2013, p. 154) úgy dönthessen a cég, hogy újra életet lehel a közel tizennégy éve szunnyadó iskolaépítési projektjébe (Huszár, 2013, p. 154).

A legjelentősebb elemi iskola, amelyet a Horthy-korszakban átadtak, az Ullmanntelepi ${ }^{8}$ elemi iskola ${ }^{9}$ volt, ahol 1928-ban kezdődött meg a tanítás. Az intézmény azonban nem feledkezett el a telkét adományozó építtetőjéről, mivel a többi városi fenntartású intézménnyel ellentétben, számos helyen utalt a bányászathoz való kötődésére, annak ellenére is, hogy soha nem volt DGT-iskola. Diákjai jelentős része azonban bányászcsaládból származott, tehát a szülők a társaság alkalmazásában álltak.

A bányászattal való szoros kapcsolatot fejezte ki a bányásziskolákban használt hivatalos köszöntés („Szerencse fel!/Jó szerencsét!”), vagy a december 4-ei, Szent Borbála-napi iskolai megemlékezések. Ez utóbbi részeként, reggel a szentmisén való részvétellel indították a napot a diákok, az iskola tőszomszédságában található Szent István-templomban.

A kötődés azonban nem csak a jeles ünnepeken mutatkozott meg, hanem a gyász pillanataiban is. A bányákban történt tragikus balesetek után iskolai megemlékezést tartottak, majd gyászmisén vettek részt a templomban, ahol mindenki számára kötelező volt a jelenlét (Mendly\& Romváry, 2005, p. 33).

Érdekesség, hogy 1945 után is megmaradt a szoros kapcsolat, mindössze annyi változás történt, hogy a tanév kezdetén az „új” bányásznapról, vagyis szeptember első vasárnapjáról is megemlékeztek az intézményben, de az egész pécsi bányavidékhez hasonlóan, a Szent Borbála-nap hagyományait is tovább ápolták az állam általi, 1950-es betiltásáig (Szita, II. kötet, 1985, p. 320).

A DGT sem szakított teljes mértékben a város számára épített oktatási intézményekkel. A társaság éves kimutatásaiból kiderül, hogy a saját iskolái mellett, 1920 és 1944 között 27000 korona önkéntes támogatást biztosított két olyan intézménynek is, amelynek fenntartója a város, illetve a Római Katolikus Egyház volt (Traj Ferenc, 2017. február 28.). Ezek egyike a már korábban említett Ullmann-telepi, míg a másik a gyárvárosi Munkás Szent József- templom mellett, az 1926 és 1931 között épített, majd 1935-ben kibővített elemi iskola volt, ahol szintén $90 \%$ körül mozgott a bányászcsaládok gyermekeinek az aránya a tanulók között (MNL DGT Z 269 17. csomó, 4. tétel).

\section{A DGT elemi iskoláinak belső élete, működése és oktatásszervezése}

\section{Az iskolai követelményrendszer}

Az iskolák éves beszámolókat készítettek az adott tanév rendjéről, menetéről. A dokumentumot a VKM mellett a DGT budapesti, illetve bécsi igazgatósági központjaiba is elküldték, ezért magyarul és németül is kiadásra kerültek. A beszámolók hasznos források

${ }^{8}$ Ma: Erzsébettelep

${ }^{9}$ Ma: Bártfa utcai Általános Iskola 
több szempontból is, mivel lényegében „kimutatásai” a korabeli naplóknak. Az osztályok létszáma (amely általában 25-30 fő körül mozgott, mert a vállalati iskolákban több tanterem is volt, így egy adott évfolyamon általában két osztályt tudtak indítani), nemzetisége, tanulmányi eredménye mellett tartalmazza az adott évben, a társulat által folyósított fenntartási összegek felhasználását is (Huszár, 2013, p. 164).

A statisztikai adatokból egyébként kiderül, hogy a diákok többsége jó tanuló volt, tehát a DGT iskoláiban színvonalas oktatás zajlott. Pótvizsgára általában kevés tanulót köteleztek, a legtöbb osztályban nem volt bukás, ahol előfordult, ott is általában egy, vagy még ritkábban két fő. Komoly gondot okozott viszont az a tény, hogy hiába írta elő az 1868-as népiskolai törvény a tankötelezettséget, számos alkalommal került sor igazolatlan hiányzásokra, amely az elemi iskolák mellett az ismétlő jellegűekre is egyaránt jellemző volt (MNL DGT Z 269 17. csomó, 3. tétel).

Az 1922-es beszámolóból értesülünk arról, hogy a német származású diákok egésze folyékonyan beszél és meg tudja értetni magát magyarul. A korábbi beszámolókban ez az információ nem szerepel, így kijelenthető, hogy az 1892-ben meghirdetett magyar oktatási nyelv „programja” huszonnyolc év múlva érte el a célját (MNL DGT Z 1359 a, 9. csomó, 6. tétel).

A teljesítés szempontjából is sokat megtudunk az intézményekben támasztott követelményrendszerről. A DGT iskolái abból a szempontból is különböztek az állami fenntartású intézményektől, hogy osztrák mintára, a teljesítményük alapján négy csoportba rangsorolták az egyes osztályokban tanuló diákokat, ${ }^{10}$ akiknek egy tanévben két alkalommal, félévkor és év végén kellett vizsga keretében számot adniuk a tudásukról (Mendly, 2005, p. 178).

Huszár Zoltán rámutat arra, hogy a beszámolók egy részében nincs feltüntetve az összes, az iskolákban tanított tantárgy, állandó jelleggel csak a magyar, illetve a német olvasás és helyesírás, valamint a számtan szerepel bennük (Huszár, 2013, p. 159).

\section{A felvételi eljárás menete, az iskolák átlagos létszáma}

A DGT kimutatásából kiderül, hogy az adott intézménybe való beiratkozáshoz nem tartozott külön felvételi, aki jelentkezett, annak biztosítva volt a hely valamelyik osztályban. Érdekesség, hogy a jogviszony csak egy tanévre vonatkozott, augusztusban minden diáknak újra be kellett iratkoznia a következő évfolyamra, nem volt automatikus a folytatás.

A beiratkozásról az állam mellett, a Pécsi Bányakapitányságon keresztül értesítették a DGT osztrák és magyar igazgatóságát is. Az erről készült jelentések azért különösen fontosak, mivel pontos adatokat közölnek arról, hogy egy-egy tanévben összesen hány diák járt egy adott intézménybe. Az adatokból kiolvasható, hogy a legtöbb tanuló valóban a két pécs-bányatelepi oktatási intézmény diákja volt, ahol 1921 után a tanulók létszáma együttesen már meghaladta a 410 főt is. A szabolcsi iskolákban a tanulók egyesített aránya ugyanebben az időben 320 fő körül mozgott, amely a második világháború kitörésekor, 1939-ben érte el a 360-at. A legkevesebb diákja a vasasi iskolának volt, mindössze alig

10 „Kitűnő rendû”, ,„Jeles rendû”, ,Első rendű”, „Másod rendű” 
kétszáz fó, és ez az arány egészen 1944-ig megmaradt. Ennek oka, hogy Vasas volt a legkisebb lélekszámú bányászkolónia és a vállalati iskolákra jellemző módon, Pécsről nem igazán jártak ki diákok az intézményekbe tanulni, igaz, fordítva sem. Az intézményben tanuló diákok száma tehát a teljes lakosság lélekszámának megfelelő arányú volt (MNL DGT Z 269 17. csomó, 3. tétel).

A DGT iskoláiban a beszámolókhoz hasonlóan minden hivatalos iratot (így az osztálynaplót és a bizonyítványt is) két nyelven, magyarul és németül vezették. Az iskolavezetőség és a tantestület összes tagjával szemben elvárás volt, hogy mind a két nyelvet beszéljék.

A XIX. század végétől a felsoroltakhoz egy harmadik, és (meglehetősen furcsa) nyelv is tartozott. Ez volt a „gráner”, amelynek használatával elsősorban a betelepült szláv származású diákokkal értette meg magát az oktató. A gráner nyelv a cseh-, morva-, és szlovén nyelvek keveredéséből alakult ki, amelyet egyedülálló módon, csak és kizárólag a pécsi bányavidéken beszéltek (Szirtes, 1999, p. 48., Márfi Attila, 2017. március 10.) mivel az 1850-es évek óta tartó együttélés eredményeképpen jött létre. ${ }^{11}$

\section{A politikai érdekek és a tanítási nyelv kérdése a DGT iskoláiban}

\section{Az Osztrák-Magyar Monarchia második felétől a Horthy-korszak második feléig (1892-1938): Magyar asszimilációs törekvések}

A vállalat összes iskolájára a működtetésük ideje alatt mindvégig egyaránt jellemző volt, hogy a tanítók a fizetésüket, és egyéb juttatásaikat is a társaságtól kapták (Huszár 2002, p. 1-2.), szolgálati alapilletményük pedig megegyezett az állami fenntartású iskolák oktatóival, de a kiegészítő járandóságaikkal együtt magasabb volt a jövedelmük, mint az állami tanítóké (Huszár, 2013, p. 169-170.).

Pécs egészen az iskolák 1948-as államosításáig jórészt kivonta magát az oktatásból, mindössze általában 1-1 tanító mondhatta el magáról, hogy a város alkalmazottjaként dolgozik az adott intézményben, de ez sem volt állandó jellegű a cég által fenntartott iskolák közel 70 éves története alatt (Huszár, 2013, p. 156).

A DGT elemi iskoláiban csak 1892 szeptemberétől vezették be Ludwig Ullmann vezérigazgató ${ }^{12}$ rendeletével a magyar nyelvű oktatást. Hivatalosan Wiesner Raymár, a pécsi bányaigazgatóság vezetője kezdeményezte (Mendly, 2005, p. 178), valójában azonban a háttérben a VKM állt, összhangban a magyar kormány asszimilációs törekvéseivel (Huszár, 2013, p. 153).

Az 1950-es évek kommunista propagandája az 1892-es váltást „nagy győelemként” értékelte „a Habsburg elnyomással” szemben. Babics András korabeli, 1952-es munkája a következőképpen taglalja a magyar nyelv bevezetését a DGT elemi iskoláiban: „A magyar nyelv bevezetése a német gyerekek számára nem nagy nehézséget(!) jelentett, mivel közel olyan jól beszélték a magyar nyelvet is, mint a németet. Jóval több akadály előtt álltak a

\footnotetext{
11 A különböző szláv dialógusok meglehetősen hasonlítanak egymásra. A „gráner” nyelv nem volt más, mind a cseh-, morva-, szlovén nyelvek furcsa egyvelege, de mégis, az 1900-as évekre a bécsi udvar elismerte a „Monarchiában divatozó nyelvek egyikeként”. A magyar állam ettől mindvégig elzárkózott.

${ }^{12}$ A vezérigazgatósága alatt benépesülni kezdő kolónia róla kapta a nevét: Ullmann-telep.
} 
magyar bányászok gyermekei a német tanítási nyelv idejében. A nehézségüket csak némileg enyhítette, hogy hetenként 2-3 órában magyar nyelven tanítottak néhány meghatározott tárgyat." (Babics, 1952, p. 144).

Mindez igaz is lehetne, csak a szerző éppen arról feledkezik el, hogy a pécsi bányászkolóniák lakosságának kb. 2/3-a német anyanyelvű volt (a diákok jelentős része mellett maguk a tanítók is), így az oktatóknak, és a tanulóknak a saját anyanyelv használata nagy valószínűséggel némi könnyebbséget jelentett a magyarral szemben. Az is megerősíti Babics állításának pontatlanságát, hogy a DGT 1922. évi társulati kiadványában kiemelt helyen szerepel, hogy a magyar származású diákok először kerültek minimális (52\%-os) többségbe a más nemzetiségűekkel szemben (MNL DGT Z 1359 a, 9. csomó, 6. tétel).

Az 1930-as években a Horthy-korszak második felének vallás-, és közoktatásügyi minisztere, Hóman Bálint oktatásügyi rendelete az ország összes iskolájában előírta „a hazafias nevelést, a magyarságtudat erősítését” a diákok számára (Ormos, 1998, p. 204), amelyhez hozzáigazították a DGT fenntartásában álló iskolák tantárgyainak és a tananyagainak jellegét is.

\section{A náci Németország befolyása alatt: Visszanémetesítési kísérlet (1938. március - 1944. november vége)}

A DGT 1938-as „Reichswerke Hermann Göring”-hez ${ }^{13}$ kerülését követően paradox helyzet állt elő, mivel a pécsi bányavidék jogilag a Magyar Királyság részét képezte, azonban az összes, üzemi, oktatásügyi, egészségügyi intézmény fenntartási joga a náci Németország irányítása alá került. Ez lényegében azt jelentette, hogy (a karhatalmi feladatokban való segédkezésen kívül) a magyar állam teljesen kiszorult a pécsi bányavidék ellenőrzéséből. A terület innentől kezdve egészen az 1950-es, a Szovjetunió általi visszaszolgáltatásáig lényegében az „állam az államban”- elv szerint működött (Babics, 1952, p. 146).

Mivel 1938 után a DGT-iskolák felügyelete kikerült a VKM illetékessége alól, ezért az intézményeket nem érintette az 1944. áprilisi magyarországi iskolabezárás sem. Az oktatás a szovjet Vörös Hadsereg 1944. novemberi bevonulásáig teljes mértékben a nácik igényei, akarata szerint működött. A döntéseket a magyar kormányzat teljes megkerülésével, Berlinben hozták, és a német öntudat erősítését követelték meg (Szirtes, I. kötet, 1993, p. 10). Ennek szellemében a pécsi bányavidék összes iskolájában visszaállították a német oktatási nyelvet, a falakról lekerült a magyar címer, amelynek helyére a náci horogkeresztet, valamint Hitler arcképét helyezték. Minden reggel, a tanítás kezdetekor idézeteket kellett felolvasni a „Führer” fő művéből, a Mein Kampfból. ${ }^{14}$ Kötelezővé tették a német hazafias-, és náci indulók éneklését, nemcsak az énekórákon, hanem a tanítási nap kezdetén, és végén is (Babics, 1952, p. 144).

${ }^{13}$ Magyar fordításban: „Hermann Göring Művek”

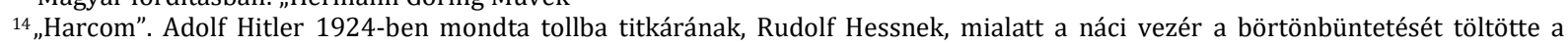
müncheni „sörpuccsért”. 


\section{A DGT elemi iskoláinak sorsa}

A szovjet Vörös Hadsereg 1944. novemberi bevonulását követően a DGT-iskolákat bezárták (Babics, 1952, p. 146). A társaság vagyonát és a pécsi bányavidéket a szovjet főparancsnok, Tolbuhin marsall a „szovjeteket ért háborús károkért szánt jóvátételnek” nyilvánította, így a hadizsákmánnyá váló ipari létesítmények egészen 1950-ig kizárólag a Szovjetuniónak termeltek és a megszállók irányítása alatt álltak. A döntést követően, 1945. áprilisában a DGT Magyarországon végleg megszűnt.

Az iskolákat ideiglenes jelleggel, a szovjet Vörös Hadsereg fenntartása alatt, 1945 őszén újraindították, de az oktatás ellenőrzését, felügyeletét hivatalosan visszautalták a VKMnek. Az előző, csonka tanévet nem ismerték el senki számára teljesítettnek, a nácikkal, az SS-szel vagy a nyilasokkal rokonszenvező, kompromittálódott, népbírósági eljárás alatt álló személyek pedig nem térhettek vissza a katedrára. Az intézményekből száműzték a nemzetiszocialista ideológiát, a könyvtárban található ilyen tartalmú tankönyveket, munkákat betiltották és bezúzták. Helyüket azonban szovjet támogatással magyar nyelvű, kommunista ideológiára is nevelő könyvek vették át (Babics, 1952, p. 152-153).

Az intézmények az 1948. június 16-ai iskolaállamosítási törvénnyel kerültek teljes egészében magyar kézbe. A korábbi DGT fenntartású iskolákban a bányászhagyományok tovább éltek, de a tanév kezdetén a hatalom által erőltetett „új” állami bányásznapról, vagyis szeptember első vasárnapjáról is meg kellett emlékezni az intézményekben, miközben az egész pécsi bányavidékhez hasonlóan, az 1950-es betiltásáig a szakrális eredetű december 4-ei Szent Borbála-nap hagyományait is tovább ápolták (Szita, II. kötet, 1985, p. 320).

A DGT egykori elemi iskolái közül az 1989/1990-es rendszerváltást követően a pécsbányatelepi és a mecsekszabolcsi intézményeket a bányabezárások, a csökkenő gyerekszám és az iskola összevonások miatt megszűntették, a somogyi és vasasi iskolák viszont napjainkban is működnek (Traj Ferenc, 2017. február 28.).

\section{Összegzés}

Írásomban arra kívántam rámutatni, hogy a DGT nem csupán egy szénkitermelő és felvásárló hajózási nagyvállalat volt, hanem komoly szerepet vállalt abban, hogy fejlessze Pécs városát, és annak vonzáskörzetét. A cég vezetősége érzékelte azt, hogy szükség van oktatási intézményekre a dolgozói által létesített és lakott bányászkolóniákon. Nemcsak azért, mert a Bach-korszakban „erősen ajánlottá” tették az iskola rendszeres látogatását, hanem abból kifolyólag is, hogy felismerték: a saját érdekük, hogy kineveljék a következő generációkat, amelyek majd átveszik nagyszüleik, szüleik helyét a bányákban, illetve a társaság által fenntartott egyéb üzemekben. Ezért a vezetőség úgy vélte, hogy már az alapoktól a saját kezébe kell vennie az oktatást. Ennek eredménye lett a pécsi bányavidék elemi iskolahálózatának kialakítása a DGT és az állam felügyelete alatt.

A pécs-bányatelepi, a mecsekszabolcsi, a somogyi és a vasasi oktatási intézményekről elmondható, hogy a különböző vizsgált történelmi korszakokban (1856-1944) a vidéki iskolák között egyértelműen a legmodernebbek közé tartoztak, és ezt a pozíciójukat 
egészen az 1944. november végi szovjet megszállásig, majd az azt követő államosításig meg is tudták őrizni.

Az iskolák közül napjainkban már csak a somogyi és a vasasi intézmények múködnek, Pécsbányatelepen ${ }^{15}$ és Mecsekszabolcson pedig emléktáblák utalnak arra, hogy a társaság mely épületeiben kaptak helyet azok az iskolák, amelyek összesen átlagosan több mint 1000 diák második „otthonának” számítottak. Olyan modern épületekben tanulhattak, amelyeknek a falai között korszerü, több tantermes, európai színvonalú könyvtárak, tornaszobák tették lehetővé azt, hogy a tudást magukba szívhassák a gyerekek.

A DGT mindig ügyelt arra, hogy iskoláiban a bányászhagyományok mellett a nemzeti ünnepek is nagy hangsúlyt kapjanak, és a magyar „hazafiasságra” való nevelés teljes mértékben érvényesülhessen. Tette ezt azért is, mivel korábban, az 1848/1849-es forradalom és szabadságharc idején a Habsburgok oldalára állt a vállalat, ezért a későbbiekben, még a századforduló idején is érték olyan vádak, hogy „túlságosan osztrák”. A „hazafias nevelés” a Horthy-korszakban érte el igazán a tetőfokát, amikor minden kötelező ünnepségen hangsúlyozták az iskolák „magyar jellegét”, legyen szó akár március 15.-ről, a Trianoni békeszerződés aláírásának évfordulójáról (június 4.), vagy Vitéz Nagybányai Horthy Miklós kormányzó névnapjáról (december 6.). ${ }^{16}$

A DGT pécsi tevékenységének megítélése sokat változott 1945 (negatív), és főleg 1989 óta (pozitív). Az oktatás területén elért vívmányairól ki lehet jelenteni, hogy valóban európai volt és nagyban hozzájárult ahhoz, hogy az ország csökkentse a lemaradását a nyugat-európai országokhoz képest.

\section{Irodalomjegyzék}

Babics A. (1952). A pécsvidéki kőszénbányászat története. Budapest: Magyar Történelmi Társulat, Közoktatásügyi Kiadóvállalat.

Gergely E. (1986). A magyarországi bányásztársadalom története 1867-ig. Budapest: Műszaki Könyvkiadó. Huszár Z. (2013). A Duna vonzásában: Fejezetek az Első Dunagőzhajózási Társaság történetéből. Pécs: Virágmandula $\mathrm{Kft}$.

Huszár Z. (2007). Integrációs kísérlet a Duna-medencében a 19. század végétől a második világháború kezdetéig. Az Első Dunagő́zhajózási Társaság (DGT/DDSG) története, pécsi bányászata, különös tekintettel a Társaság pécsi szociális és oktatási infrastruktúrájára. Pécs: Pécsi Tudományegyetem Bölcsészettudományi Kar, Interdiszciplináris Doktori Iskola. http://www.idi.btk.pte.hu/dokumentumok/disszertaciok/huszarzoltanphd.pdf. Letöltés dátuma: 2017. június 1.

Huszár Z. (2009). Die Donau als Kulturbrücke und Integrationsfaktor. In Wichard, R. (Eds.), Brücken zwischen den Kulturen. Geistige Grundlagen. Historische Beispiele. Zeitfragen. Frankfurt am Main: Stiftung Haus der Action 365.

Huszár Z. (2010). Multiethnische Beziehungen im Bergbaurevier der Donau-Dampschifffahrtsgesellschaft in der Umgebung von Pécs von der Mitte des 19. Jahrhunderts bis zum Zweiten Weltkrieg. In Wichard, R. (Eds.), Kreuzwege. Kulturbegegnung im öffentlichen Raum. Frankfurt am Main: Stiftung Haus der Action 365. Katus L. (2010). A modern Magyarország születése. Magyarország története 1711-1914.

Egyetemi tankönyv. Pécs: Pécsi Történettudományért Kulturális Egyesület - Bocz Nyomdaipari Kft.

151950 óta hivatalosan ebben a formában használják a településrész nevét.

${ }^{16}$ A kormányzó december 6-ai,„névünnepét” összevonták az azt egy nappal megelőző Szent Borbála-nappal, így a pécsi bányavidék iskoláiban két napos ünnepségekkel tisztelték meg a „jeles” évfordulókat december első napjaiban. 
Mendly L. (2005). A (közel)150 éves András-akna. Bányászati és Kohászati Lapok, 136 (3), 216-225.

Mendly L. \& Romváry F. (szerk.).(2005). Emléklapok a pécsi szénbányászat történetéből. Örökségi Füzetek 3. Pécs: Pécs/Sopianae Örökség Kht.- Pécsi Bányásztörténeti Alapítvány-Pécsi Szemle Várostörténeti Alapítvány.

Romváry F. (szerk.).(2008). Újabb emléklapok a pécsi szénbányászat történetéből. Pécs: Bocz Nyomdaipari Kft.

Ormos M. (1998). Magyarország a két világháború korában. 1914-1945. Debrecen: Csokonai Kiadó. Pálfy A. (2005). Szabolcsfalu. In Mendly L. (szerk.), A Pécsi Szénbányászat szerepe a város XX. századi fejlődésében (261-270). Pécs: Bocz Nyomdaipari Kft.

Pilkhoffer M. (2010). Az Első Dunagőzhajózási Társaság pécsi kolóniáinak kiépülése a dualizmus korában. In Márfi A. (szerk.), Utcák, terek, épületek Pécsett. Baranyai történelmi közlemények 4 (135-164). Pécs: Baranya Megyei Levéltár.

Szirtes B. (szerk.).(1993). A mecseki kőszénbányászat. 1945-1991. I. kötet. Pécs: Kútforrás Kft.

Szita L. (szerk.). (1985). A baranyai-pécsi munkásmozgalom története (1867-1944.) II. kötet. Pécs: Baranya Megyei Levéltár.

Szirtes B. (1999). Kik azok a gránerek? Pécsi Szemle Várostörténeti Folyóirat, 2 (ősz), 47-55.

Levéltári források:

Magyar Nemzeti Levéltár (a továbbiakban: MNL), Az Első Dunagőzhajózási Társaság (a továbbiakban: DGT) Iratanyagai: Általános iratok. Z 1359 a, Emlékeztetők (1913-1946).

9. csomó, 6. tétel: Jahrbuch der Deutschen Verkehrs-Gewerkschaft Bezirksverband der Binnenschiffer 1921-1922,Wien, 1922. p. 10.

MNL, DGT: A DGT Pécsi bányaigazgatóságának általános iratai. Z 269 17. csomó, 1. tétel: A DGT pécsi bányaiskoláinak tanulói létszáma (1856-1892). A, Pécs-Bányatelep.

MNL, DGT: A DGT Pécsi bányaigazgatóságának általános iratai. Z 269 17. csomó, 1. tétel: A DGT pécsi bányaiskoláinak tanulói létszáma (1856-1892). B, Mecsekszabolcs.

MNL, DGT: A DGT Pécsi bányaigazgatóságának általános iratai. Z 269 17. csomó, 1. tétel: A DGT pécsi bányaiskoláinak tanulói létszáma (1856-1892). C, Vasas.

MNL, DGT: A DGT Pécsi bányaigazgatóságának általános iratai. Z 269 17. csomó, 1. tétel: A DGT pécsi bányaiskoláinak tanulói létszáma (1856-1892). D, Somogy.

MNL, DGT: A DGT Pécsi bányaigazgatóságának általános iratai. Z69 17. csomó, 2. tétel: A DGT pécsi bányaiskoláinak tanítói létszáma (1856-1892).

MNL, DGT: A DGT Pécsi bányaigazgatóságának általános iratai. Z 269 17. csomó 3. tétel: A DGT által Pécs városa számára épített iskoláik tanulói Létszám aránya. (1928-1944).

MNL, DGT: Építési osztály Z 271 d, Jóléti, és kommunális létesítmények. Lakóépületek. 84. csomó, 155. tétel: Iskolák, és napközi otthonok, játszótér (1872-1942.)

Oral history:

Márfi Attila, a Magyar Nemzeti Levéltár Baranya Megyei Levéltárának (MNL BaML) nyugdíjas főlevéltárosa, egykori pécsbányatelepi lakos. (Interjúkészítés: 2017. március 10.)

Traj Ferenc, a Mecseki Szénbányák nyugdíjasa, a Bányászemlékekért Egyesület (BEE) alapító tagja, tiszteletbeli elnöke. (Interjúkészítés: 2017. február 28.) 


\section{Melléklet}

1. sz. melléklet: A DGT által épített, és múködtetett Pécs-bányatelepi, „alsó” elemi iskola épülete az 1920-as években.

Forrás: Pécsi Bányásztörténeti Alapítvány

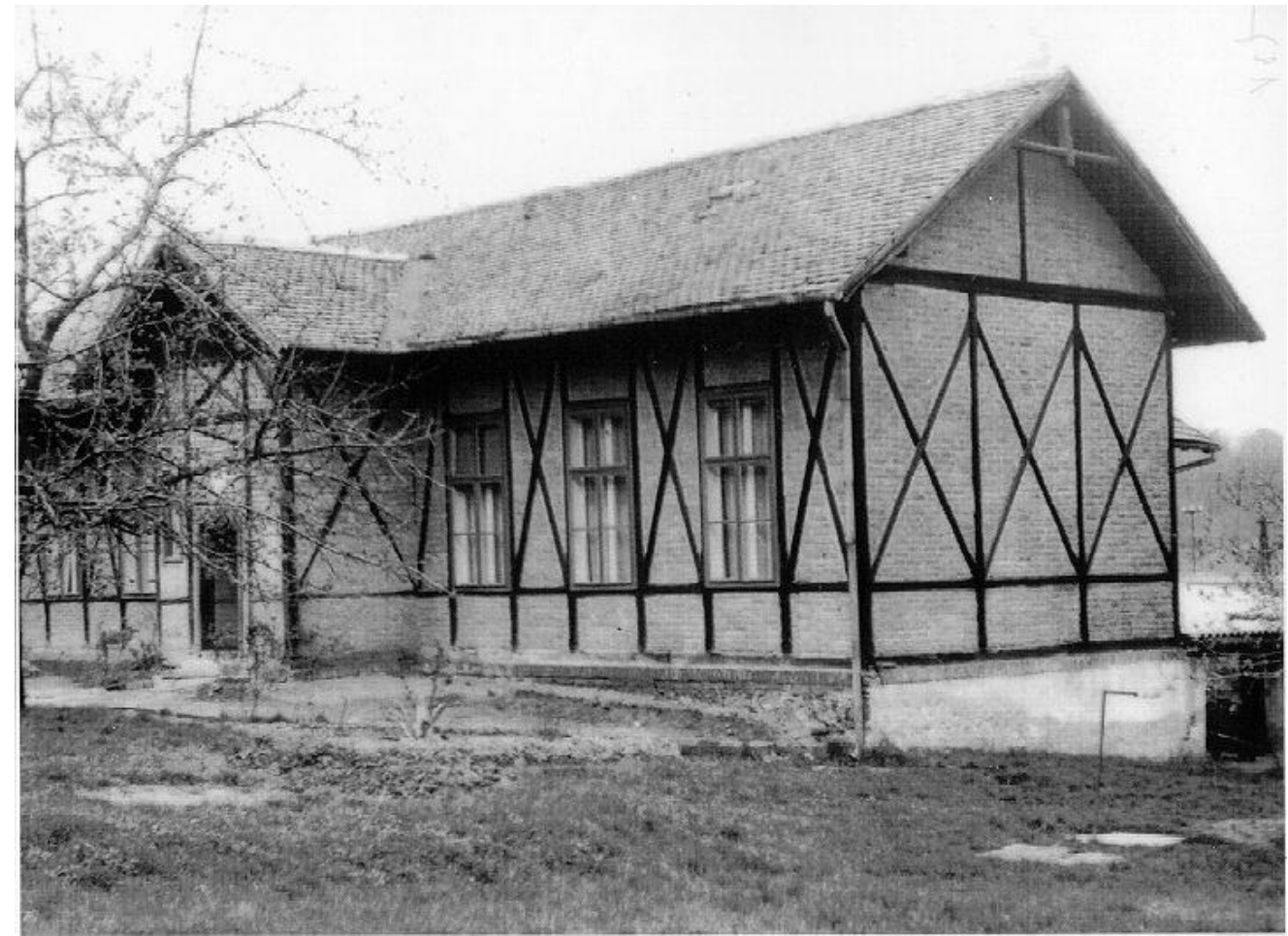

2. sz. melléklet: A DGT által építetett és működtetett, egykori mecsekszabolcsi elemi iskola épülete (ma: Közösségi ház) napjainkban.

Forrás: Pécsi Bányásztörténeti Alapítvány

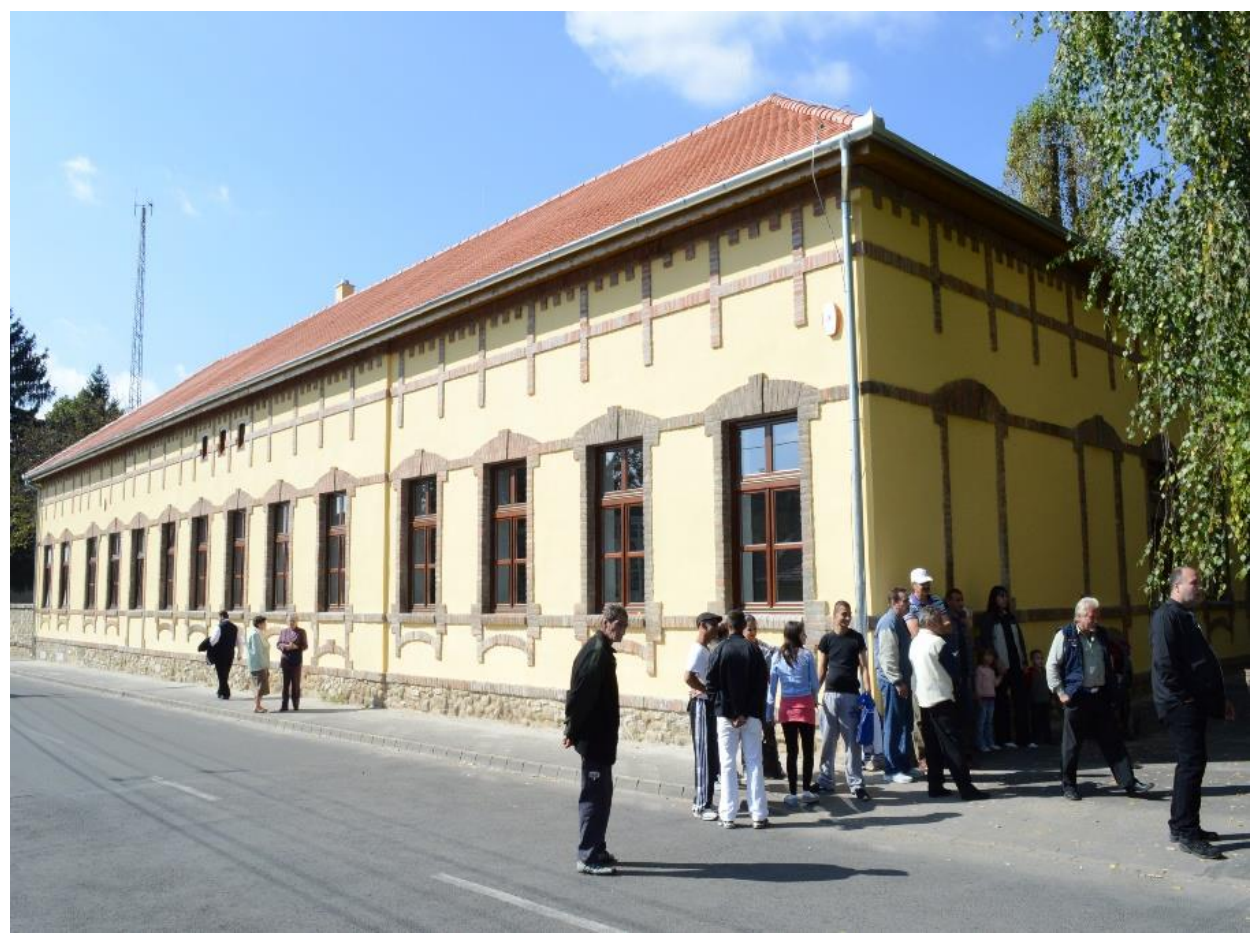


3. sz. melléklet: A DGT által múködtetett György-aknai elemi iskola (Mecsekszabolcsi „felső” elemi iskola) második osztályos diákjainak osztályképe az 1910/1911-es tanévben.

Forrás: Pécsi Bányásztörténeti Alapítvány

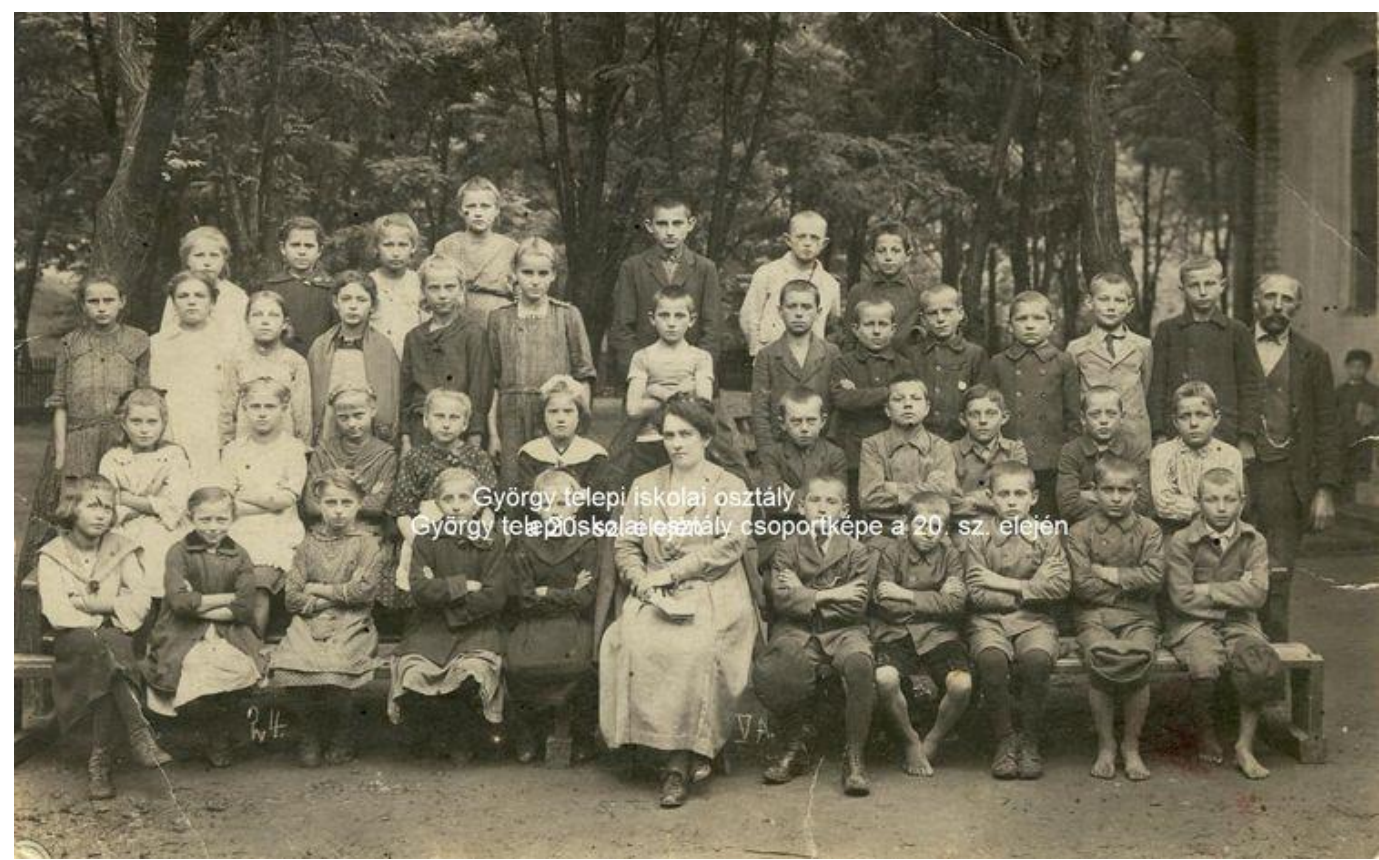

4. sz. melléklet: A DGT által múködtetett, somogyi elemi iskola az 1950-es években átalakított épülete napjainkban.

Forrás: Pécsi Bányásztörténeti Alapítvány

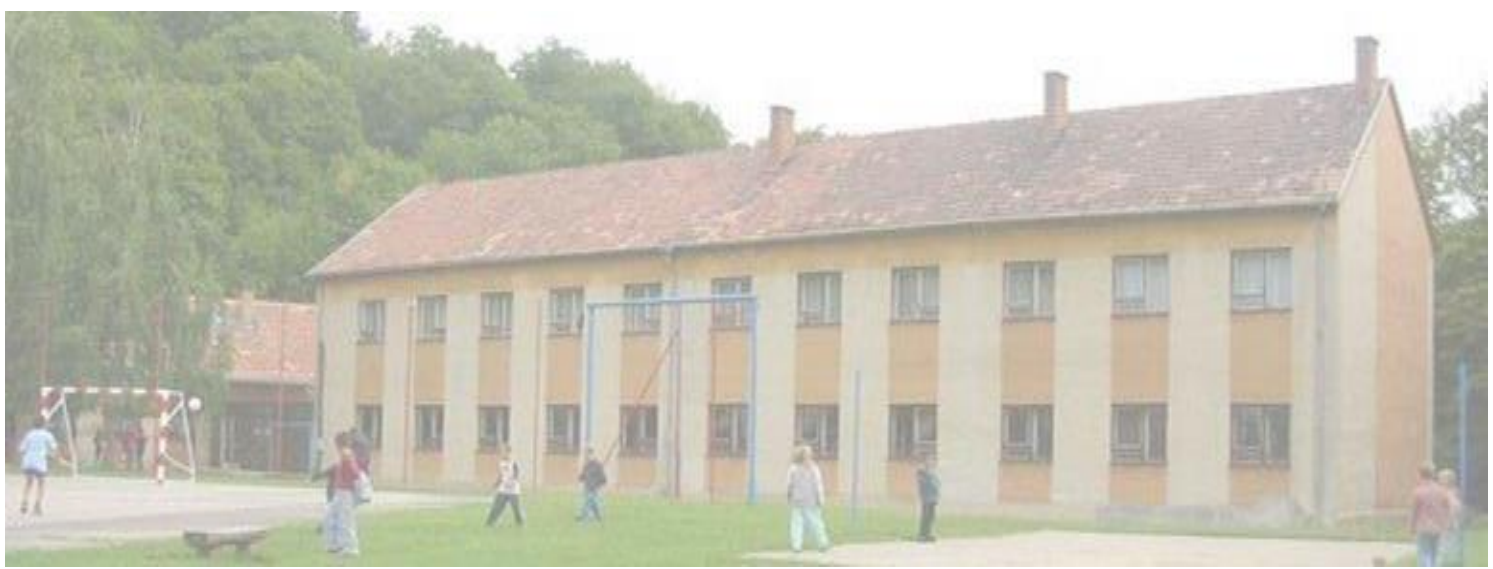


5. sz. melléklet: A DGT által, a város számára épített Ullmann-telepi elemi iskola (ma: Bártfa utcai Általános Iskola) eredeti épülete az 1920-as évek végén.

Forrás: Pécsi Bányásztörténeti Alapítvány

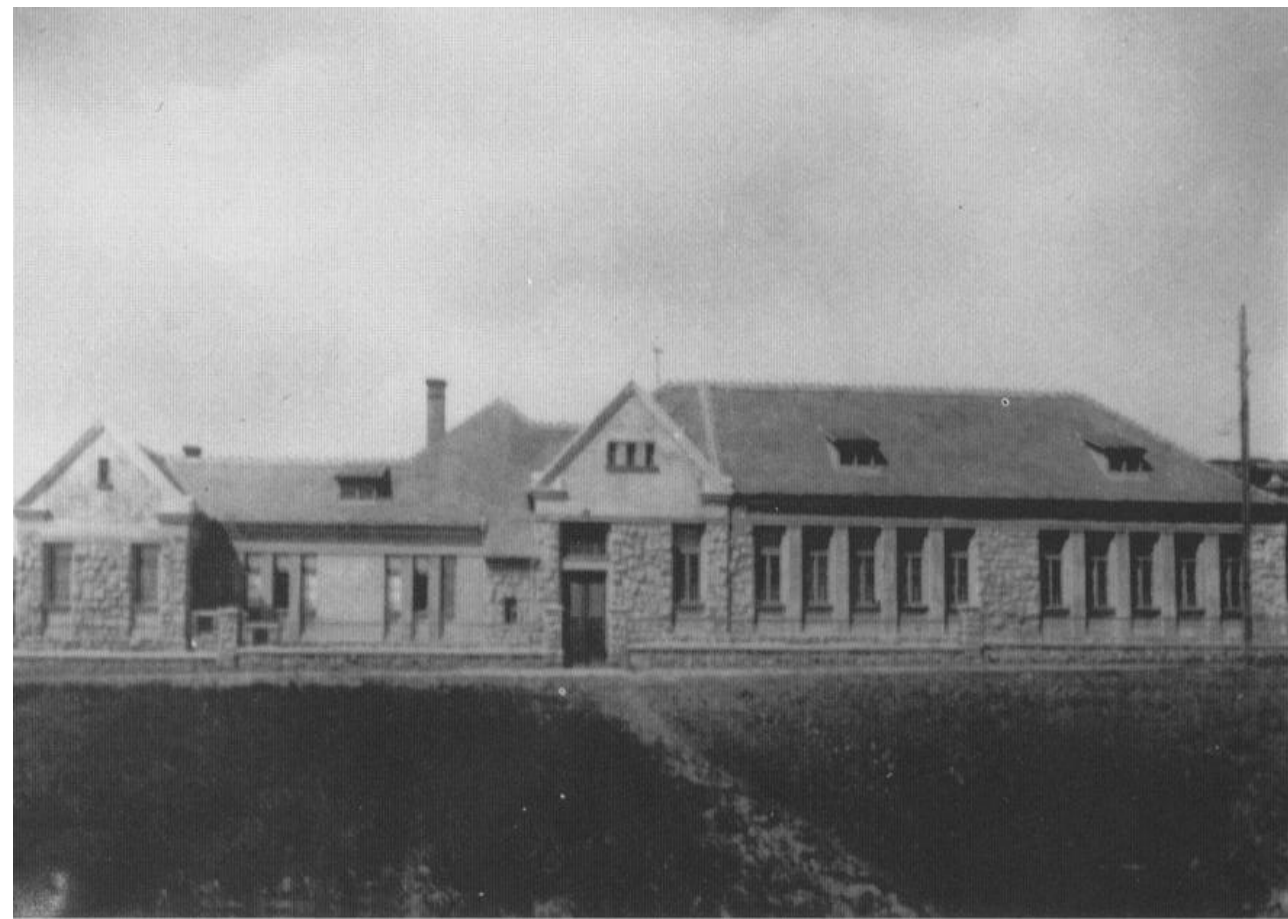

6. sz. melléklet: A DGT által, a város számára épített egykori Ullmann-telepi elemi iskolának (ma: Bártfa utcai Általános Iskola) az 1950-es években átalakított épülete napjainkban.

Forrás: Pécsi Bányásztörténeti Alapítvány

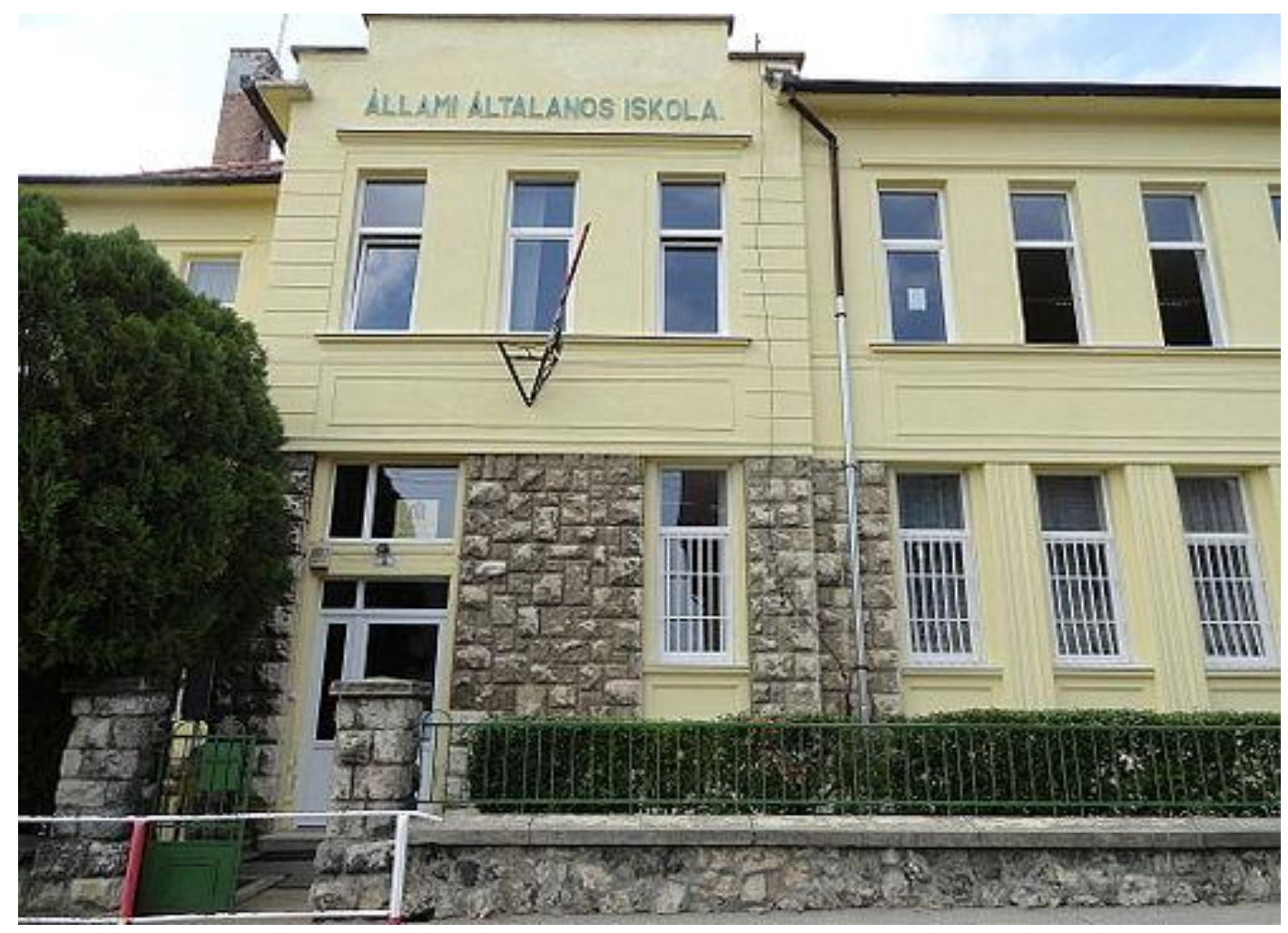


7. sz. melléklet: A DGT által, a város számára épített Gyárvárosi elemi iskolának az épülete napjainkban. Forrás: Pécsi Bányásztörténeti Alapítvány

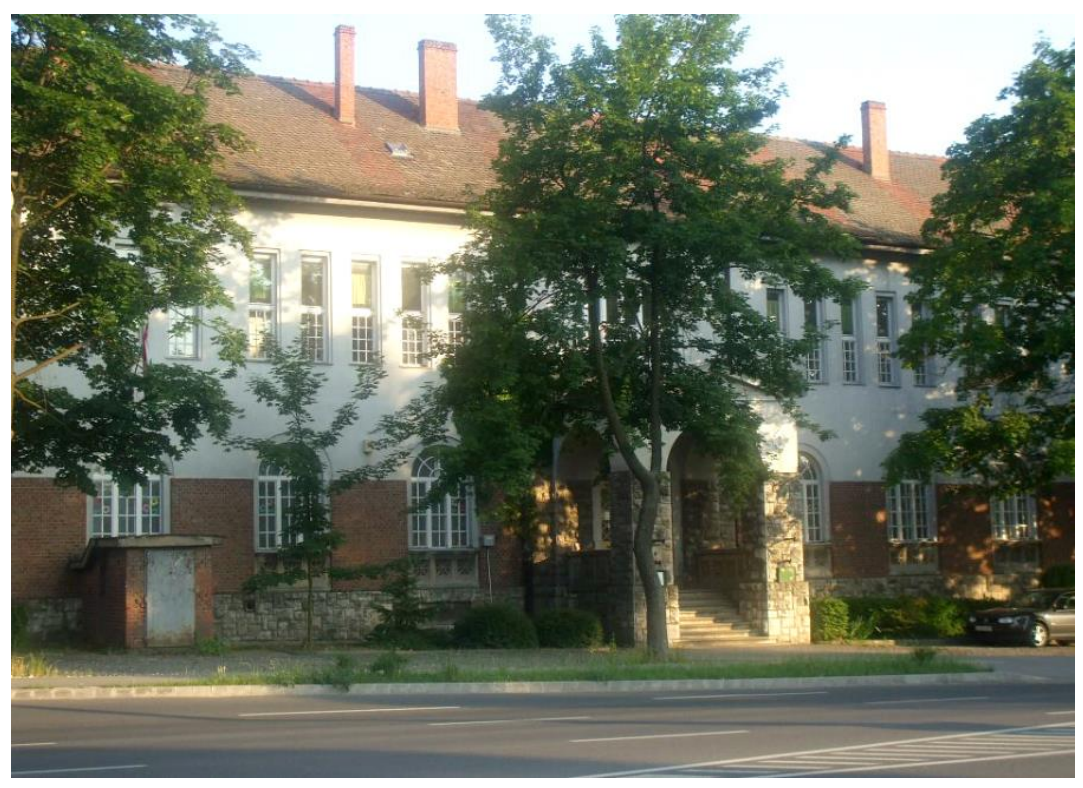

